\title{
Characterization of enterobacteria by esterase specific-activity profiles
}

\author{
Philippe Goullet* and Bertrand Picard
}

\begin{abstract}
Laboratoire de Microbiologie, Faculté de Médecine Xavier Bichat (Université Paris VII), 16 rue Henri Huchard, 75018 Paris, France
\end{abstract}

(Received 16 August 1989; revised 13 November 1989; accepted 8 December 1989)

\begin{abstract}
The spectrum of specific activities and the electrophoretic mobilities of esterases produced by 550 strains of Enterobacteriaceae belonging to 36 species and subclassified into six groups (group 1, Escherichia coli, Shigella and Escherichia hermanii; group 2, genus Salmonella and genus Citrobacter; group 3, genus Klebsiella and genus Enterobacter; group 4, genus Serratia and Serratia fonticola; group 5, genus Proteus, genus Providencia and genus Morganella; and group 6, genus Yersinia) were analysed by acrylamide/agarose gel electrophoresis using standardized methods for staining and mobility comparisons. Nineteen types of esterase were defined by their respective esterase specific-activity profile (ESAP). A multiple correspondence analysis (MCA) of the ESAP data enabled $82 \%$ of the strains in the 36 species to be correctly classified. In each group, the species were clearly delineated after MCA on both ESAP and electrophoretic mobility data. In addition, the smallest number of characters providing species identification of Yersinia strains by esterase polymorphism was identified by means of a binary segmentation tree technique.
\end{abstract}

\section{Introduction}

The classification of enterobacteria is based mainly on a combination of data provided by DNA-DNA hybridization studies and conventional phenotypic characters. However, enzyme electrophoresis has been shown to be a powerful tool for studying classification, population genetics and epidemiology. Oxidoreductases were the first enzymes studied (Bowman et al., 1967; Baptist et al., 1969), but esterases have been more widely used; 36 species belonging to Escherichia (Goullet, 1973; Goullet et al., 1986), Shigella (Goullet, 1980b), Proteus and Providencia (Goullet, 1975; Goullet \& Picard, 1985), Salmonella (Goullet, 1977), Citrobacter (Goullet \& Richard, 1977), Klebsiella, Enterobacter (Goullet, 1980a; Goullet \& Picard, 1986), Serratia (Goullet, 1978, 1981) and Yersinia (Goullet \& Picard, 1984, 1988) have been investigated. More recently, multilocus enzyme electrophoresis, analysing in particular oxidoreductases and transferases, has been used for comparisons between and within E. coli and Shigella (Ochman et al., 1983) and within Salmonella (Reeves et al., 1989; Beltran et al., 1989 ) and Serratia marcescens (Gargallo-Viola, 1989).

In the 36 enterobacterial species investigated, many

\footnotetext{
Abbreviations: DFP, di-isopropyl fluorophosphate: ESAP, esterase specific-activity profile; MCA, multiple correspondence analysis; $M_{R}$, relative electrophoretic mobility; PCA, principal component analysis.
}

varieties of esterase were identified by the zymogram procedure on the basis of their spectrum of hydrolytic activity toward various substrates and their sensitivity or resistance to di-isopropyl fluorophosphate (DFP). Moreover these enzymes displayed great electrophoretic polymorphism. Thus, in contrast to most other enzymes, which differentiate bacteria only by their electrophoretic mobilities, the esterases can distinguish taxa both by their specific activity profiles and by their electrophoretic mobilities. The present work was done in order to determine the respective contributions of each of these two characteristics for inter- and intraspecies differentiation of the 36 species by means of standardized methods for esterase staining and electrophoretic mobility determination. Our findings demonstrate the considerable taxonomic value of esterase specific-activity profiles (ESAP) for characterizing genospecies, whereas the electrophoretic mobilities of the enzymes provide valuable information for delineating inter-related species.

\section{Methods}

Bacterial strains. The strains tested were those previously studied: Shigella flexneri (13 strains), S. sonnei (13 strains), S. boydii (14 strains) and $S$. dysenteriae (13 strains) (Goullet, 1980b); Escherichia hermanii (11 strains) (Goullet et al., 1986); Citrobacter freundii (14 strains), $C$. diversus (Levinea malonatica) (14 strains) and $C$. amalonaticus ( $L$. amalonatica) (14 strains) (Goullet \& Richard, 1977); Klebsiella pneumoniae (14 strains), K. oxytoca (14 strains), Enterobacter aerogenes 
(16 strains) and E. gergoviae (16 strains) (Goullet, 1980a); E. sakazakii (22 strains) (Goullet \& Picard, 1986); Serratia marcescens (16 strains), $S$. liquefaciens (16 strains), S. plymuthica (15 strains) and S. marinorubra (15 strains) (Goullet, 1978); S. odorifera (15 strains), S. ficaria (13 strains), $S$. fonticola (14 strains) (Goullet, 1981); Proteus vulgaris (12 strains), $\boldsymbol{P}$. mirabilis (12 strains), Providencia stuartii (17 strains), $\boldsymbol{P}$. rettgeri (11 strains) and Morganella morganii (12 strains) (Goullet, 1975); P. rustigianii (17 strains) (Goullet \& Picard, 1985); Yersinia pseudotuberculosis (16 strains) (Goullet \& Picard, 1984); and $Y$. frederiksenii (20 strains) (Goullet \& Picard, 1988). For the other species, only strains showing a distinct esterase electrophoretic pattern were analysed: $E$. coli (12 strains) (Goullet, 1980 b); Salmonella enterica (21 strains) (Goullet, 1977); Enterobacter cloacae (25 strains) (Goullet \& Picard, 1986); Providencia alcalifaciens (16 strains) (Goullet \& Picard, 1985); $Y$. enterocolitica (17 strains) (Goullet \& Picard, 1984); and $Y$. intermedia (16 strains), $Y$. kristensenii (19 strains) and $Y$. aldovae (15 strains) (Goullet \& Picard, 1988).

The 36 species were subclassified into six groups: group $1, E$. coli, Shigella and E. hermanii; group 2, genus Salmonella and Citrobacter; group 3, genus Klebsiella and Enterobacter; group 4, genus Serratia and S. fonticola; group 5, genus Proteus, Providencia and Morganella; and group 6, genus Yersinia.

Preparation of bacterial extracts. Bacteria were grown in L-broth (Lennox, 1955) at $37^{\circ} \mathrm{C}$ (except for Yersinia strains which were grown at $28{ }^{\circ} \mathrm{C}$ ) for $18 \mathrm{~h}$ with agitation in a reciprocating water-bath shaker at about 70 oscillations $\min ^{-1}$. The cells were centrifuged, washed twice with $0.06 \mathrm{M}$-Tris/glycine buffer, $\mathrm{pH} 8 \cdot 7$, resuspended in the same buffer and disrupted by intermittent sonic oscillations (Sonifier cell disruptor B30; Branson) for $6 \mathrm{~min}$ at $4^{\circ} \mathrm{C}$. Cell debris was removed by centrifugation at $20000 \mathrm{~g}$ for $20 \mathrm{~min}$ at $4{ }^{\circ} \mathrm{C}$. The crude extracts, containing 40 to $60 \mathrm{mg}$ protein $\mathrm{ml}^{-1}$, were stored at $-20^{\circ} \mathrm{C}$ until used.

Electrophoretic analysis. Horizontal slab acrylamide/agarose gel electrophoresis $(7 \% \mathrm{w} / \mathrm{v}$, acrylamide, $0.8 \%$ agarose, Tris/glycine buffer, $\mathrm{pH} \mathrm{8.6)}$ were performed as described previously (Uriel, 1966; Goullet, 1973).

Characterization of esterases. Esterases were stained as described previously (Uriel, 1963; Goullet, 1973) using $\alpha$-naphthyl acetate, propionate and butyrate, $\beta$-naphthyl acetate, propionate and butyrate, and indoxyl acetate. Precise standardization of hydrolytic activity in gels towards naphthyl esters was obtained by staining for exactly 45 min at room temperature; the reaction was stopped by addition of $0.1 \mathrm{M}$-acetic acid. (An exception was indoxyl acetate staining, which was continued overnight.) Inhibition by DFP $\left(10^{-3} \mathrm{M}\right)$ was determined in crude extracts which were allowed to stand for $30 \mathrm{~min}$ at room temperature before electrophoresis.

Electrophoretic mobility determinations. The reproducibility of the electrophoretic mobility measurements was optimized by measuring the relative electrophoretic mobility values ( $M_{R}$ value) using a reference mobility scale of six esterases : esterase A and B from Shigella sonnei strain 2.77 (Goullet, 1980b); esterase B from E. coli strain FM2 (Goullet, 1973); esterase M from Aeromonas hydrophila strain 66 (Picard \& Goullet, 1985); esterase $\mathrm{E}_{\mathrm{BA}}$ from $Y$. intermedia strain $\mathrm{CNY}$ 87.70 (Goullet \& Picard, 1988) and esterase $P_{4}$ from $Y$. pseudotuberculosis strain CNY 1833 (Goullet \& Picard, 1984). The $M_{R}$ value of a given variant was measured within the appropriate mobility range as the ratio between the distance measured from the slow reference esterase to the band of the variant and the distance measured from the slow reference esterase to the fast reference esterase.

Statistical analysis. A multiple correspondence analysis (MCA) (Greenacre, 1984; Lebart et al., 1984; Tenenhaus \& Young, 1985) was done by means of the SPAD.N program (Centre International de Statistique et d'Informatique Appliquées, Paris, France) from a table containing 19 variables (the types of esterase) and 550 rows (the strains). MCA was then done for each of the six groups of species, including both the type of esterase and the esterase electrophoretic mobilities. For this purpose, three to five ranges of mobility were delineated according to the histograms of the $M_{R}$ values of each esterase type within each group of species. A principal component analysis (PCA) was done with the $M_{R}$ data for the 19 enzymes and compared to the results of the MCA. For each MCA, a hierarchical classification using Ward's criteria was done based on the eight first axes of the analysis and a dendrogram was obtained. The number of axes on which this analysis was done corresponded to the structural and stable portions of the variance whereas the rest of the variance corresponded to random noise and thus was discarded for the hierarchical classification. The number of classes corresponding to the number of species considered in each analysis was selected, and the strain compositions of the final classes were compared to those of the corresponding species. MCA is an eigenvector method of ordination similar to PCA. It differs from the latter in the use of a covariance matrix of $\chi^{2}$ distances rather than a covariance matrix of Euclidean distances. Both techniques describe the dispersion or shape of a cloud of $n$ objects or $p$ variates in a multi-dimensional space by replacing the original data set by a new set of orthogonal linear coordinates in a space of significantly lower dimension. The explained variances of the elements of the data set are in decreasing order of magnitude with respect to these derived coordinates (Lebart et al., 1984). Furthermore, the variables used for MCA are categories whereas those used for PCA are quantitative or continuous variables. Finally, a binary segmentation tree (Gueguen \& Nakache, 1988) was obtained from the data of the MCA done on Yersinia strains (group 6).

\section{Results and Discussion}

\section{Esterase characterization}

The 146 distinct esterase bands previously described for the 36 species can be regrouped into 19 principal types (Table 1) on the basis of their hydrolytic activities on the seven synthetic substrates and of their sensitivity to DFP. Types 1,3 to 7,9 to $12,14,16$ and 17 correspond to DFP-sensitive esterases and types 2, 8, 13, 15, 18 and 19 correspond to DFP-resistant esterases. Eight types of esterases showing comparable activity towards $\alpha$ - and $\beta$ naphthyl acetates were designated $\alpha-\beta$ esterases. Five of these hydrolysed the five other substrates and were distinguished from each other by their differential activity on acetyl (A), propionyl $(P)$ and butyryl (B) esters as follows. Types 1 and $2, \mathrm{~A}>\mathrm{P}>\mathrm{B}$; type $3, \mathrm{~A}<\mathrm{P} \approx \mathrm{B}$; type $4, \mathrm{~A} \approx \mathrm{P} \approx \mathrm{B}$; type $5, \mathrm{~A} \approx \mathrm{P}>\mathrm{B}$. Type 6 was active on all substrates except $\beta$-naphthyl butyrate. Type 7 was active on the three acetyl esters and on $\alpha$-naphthyl propionate. Type 8 was active on $\alpha$ - and $\beta$-naphthyl acetates. Seven types of esterases (types 9 to 15) hydrolysed mainly $\alpha$-naphthyl esters and were designated $\alpha$-esterases. Type 9 hydrolysed $\alpha$ - and $\beta$-naphthyl esters and indoxyl acetate. Enterobacter gergoviae esterase $\mathrm{E}_{4}$ may be distinguished from other enzymes of this type by its greater activity towards $\beta$-naphthyl esters. Type 10 was distinguished from type 9 by its inactivity on $\beta$ - 
Table 1. Distribution of the 146 previously described esterase bands within the 19 types of esterase and the 36 species of enterobacteria

For each species, esterases are designated as in previous papers (see Methods for references). Consequently, the same designation can correspond to esterases belonging to distinct types, e.g. esterases $\mathrm{E}_{1}$ of Serratia fonticola, Citrobacter diversus, Serratia odorifera, Klebsiella pneumoniae, Salmonella enterica and Escherichia hermanii correspond to types 3, 7, 8, 10,13 and 17, respectively.

\begin{tabular}{|c|c|c|c|c|c|c|c|c|c|c|c|c|c|c|c|c|c|c|c|c|c|}
\hline \multirow{2}{*}{$\begin{array}{c}\text { Species } \\
\text { no. }\end{array}$} & & \multicolumn{8}{|c|}{$\alpha-\beta$-Esterases } & \multicolumn{7}{|c|}{$\alpha$-Esterases } & \multicolumn{4}{|c|}{$\beta$-Esterases } & \multirow[b]{2}{*}{ Tota } \\
\hline & & 1 & $2^{*}$ & 3 & 4 & 5 & 6 & 7 & $8^{*}$ & 9 & 10 & 11 & 12 & $13^{*}$ & 14 & $15^{*}$ & 16 & 17 & $18^{*}$ & $19^{*}$ & \\
\hline $\begin{array}{l}1 \\
2 \\
3 \\
4 \\
5 \\
6\end{array}$ & $\begin{array}{l}\text { Group } 1 \\
\text { Escherichia coli } \\
\text { Shigella flexneri } \\
\text { Shigella sonnei } \\
\text { Shigella boydii } \\
\text { Shigella dysenteriae } \\
\text { Escherichia hermanii }\end{array}$ & & & & & & & & $E_{4}$ & $\begin{array}{l}\text { B } \\
\text { B } \\
\text { B } \\
\text { B }\end{array}$ & $\begin{array}{l}\mathbf{A} \\
\mathbf{A} \\
\mathbf{A} \\
\mathbf{A} \\
\mathbf{A} \\
\mathbf{E}_{6}\end{array}$ & & $\mathrm{E}_{2}$ & & & $\begin{array}{l}\text { I } \\
\text { I } \\
\text { I } \\
\text { I } \\
\text { I }\end{array}$ & $\begin{array}{l}S \\
S \\
S \\
S \\
S \\
E_{5}\end{array}$ & $\begin{array}{l}F \\
F \\
F \\
F \\
F \\
E_{1}\end{array}$ & $\begin{array}{l}\mathrm{C} \\
\mathrm{C} \\
\mathrm{C} \\
\mathrm{C} \\
\mathrm{C}\end{array}$ & & $\begin{array}{l}6 \\
6 \\
6 \\
6 \\
5 \\
5\end{array}$ \\
\hline $\begin{array}{r}7 \\
8 \\
9 \\
10\end{array}$ & $\begin{array}{l}\text { Group } 2 \\
\text { Salmonella enterica } \\
\text { Citrobacter freundii } \\
\text { Citrobacter diversus } \\
\text { Citrobacter amalonaticus }\end{array}$ & & & & & & & $\mathrm{E}_{1}$ & & $\begin{array}{c}\mathbf{E}_{3} \\
\text { Major } \\
\mathrm{E}_{3} \\
\text { Major }\end{array}$ & $E_{2}$ & & & $E_{1}$ & $E_{4}$ & & $\mathbf{S}$ & $\begin{array}{l}F \\
F\end{array}$ & $\mathbf{E}_{2}$ & & $\begin{array}{l}6 \\
1 \\
4 \\
1\end{array}$ \\
\hline $\begin{array}{l}11 \\
12 \\
13 \\
14 \\
15 \\
16\end{array}$ & $\begin{array}{l}\text { Group } 3 \\
\text { Klebsiella pneumoniae } \\
\text { Klebsiella oxytoca } \\
\text { Enterobacter aerogenes } \\
\text { Enterobacter gergoviae } \\
\text { Enterobacter cloacae } \\
\text { Enterobacter sakazakii }\end{array}$ & & $\mathbf{E S}_{2}$ & & & & $\mathrm{ES}_{4}$ & & $\begin{array}{l}\mathrm{m}_{3} \\
\mathrm{~m}_{3} \\
\mathrm{EC}_{3}\end{array}$ & $\mathbf{E}_{4}$ & $\begin{array}{c}E_{1} \\
E_{1} \\
E_{1} \\
E_{1} \\
E_{4}\end{array}$ & & $\mathrm{E}_{3}$ & $\begin{array}{l}\mathrm{E}_{2} \\
\mathrm{~m}_{7} \\
\mathrm{EC}_{1} \\
\mathrm{ES}_{1}\end{array}$ & $\begin{array}{l} \\
\mathrm{EC}_{2} \\
\mathrm{ES}_{3}\end{array}$ & & & $\begin{array}{l}\text { F } \\
\text { F } \\
F\end{array}$ & $\begin{array}{l}\mathrm{m}_{2} \\
\mathrm{~m}_{2} \\
\mathrm{~m}_{6}\end{array}$ & & $\begin{array}{l}4 \\
3 \\
4 \\
5 \\
4 \\
4\end{array}$ \\
\hline $\begin{array}{l}17 \\
18 \\
19 \\
20 \\
21 \\
22 \\
23\end{array}$ & $\begin{array}{l}\text { Group } 4 \\
\text { Serratia marcescens } \\
\text { Serratia liquefaciens } \\
\text { Serratia plymuthica } \\
\text { Serratia marinorubra } \\
\text { Serratia odorifera } \\
\text { Serratia ficaria } \\
\text { Serratia fonticola }\end{array}$ & & & $\mathrm{E}_{1}$ & $\begin{array}{l}\mathbf{E}_{3} \\
\mathbf{E}_{3} \\
\mathbf{E}_{3} \\
\mathbf{E}_{3}\end{array}$ & $E_{5}$ & & & $\begin{array}{l}E_{2} \\
E_{2} \\
E_{2} \\
E_{1} \\
E_{1}\end{array}$ & & $\begin{array}{l}\mathbf{E}_{1} \\
\mathbf{E}_{1} \\
\mathbf{E}_{1} \\
\mathbf{E}_{1} \\
\mathbf{E}_{3} \\
\mathbf{E}_{2}\end{array}$ & & & & $\mathbf{E}_{2}$ & & $\begin{array}{l}\mathbf{E}_{5} \\
\mathbf{E}_{5} \\
\mathbf{E}_{5} \\
\mathbf{E}_{5}\end{array}$ & $\begin{array}{c}\mathrm{Em}_{2} \\
\mathrm{~F} \\
\mathrm{~F}\end{array}$ & & $\begin{array}{l}E_{4} \\
E_{4} \\
E_{4} \\
E_{4} \\
E_{4} \\
E_{4}\end{array}$ & $\begin{array}{l}5 \\
5 \\
4 \\
4 \\
5 \\
5 \\
4\end{array}$ \\
\hline $\begin{array}{l}24 \\
25 \\
26 \\
27 \\
28 \\
29 \\
30\end{array}$ & $\begin{array}{l}\text { Group } 5 \\
\text { Proteus vulgaris } \\
\text { Proteus mirabilis } \\
\text { Providencia alcalifaciens } \\
\text { Providencia stuartii } \\
\text { Providencia rettgeri } \\
\text { Providencia rustigianii } \\
\text { Morganella morganii }\end{array}$ & $\alpha \beta$ & & & & & & & & $\mathbf{E} \alpha \mathbf{A}$ & & $\begin{array}{l}E \propto A B \\
E \propto A B\end{array}$ & $\begin{array}{l}\mathbf{E} \alpha \\
\mathbf{E} \alpha\end{array}$ & $\mathbf{E} \alpha$ & $\alpha \mathrm{a}$ & & $\begin{array}{l}\beta \mathrm{B} \\
\beta \mathrm{B} \\
\beta \mathrm{A} \\
\beta \mathrm{A} \\
\beta \mathrm{A} \\
\beta \mathrm{A}\end{array}$ & & & & $\begin{array}{l}2 \\
2 \\
3 \\
2 \\
3 \\
1 \\
2\end{array}$ \\
\hline $\begin{array}{l}31 \\
32 \\
33 \\
34 \\
35 \\
36\end{array}$ & $\begin{array}{l}\text { Group } 6 \\
\text { Yersinia pseudotuberculosis } \\
\text { Yersinia enterocolitica } \\
\text { Yersinia intermedia } \\
\text { Yersinia frederiksenii } \\
\text { Yersinia kristensenii } \\
\text { Yersinia aldovae }\end{array}$ & & $\mathbf{E}_{4}$ & $\mathbf{E}_{\mathrm{BA}}$ & & & & & $\begin{array}{l}E_{2} \\
E_{2} \\
E_{2} \\
E_{2} \\
E_{2}\end{array}$ & $\underset{E_{3} E_{5}}{P_{4}}$ & & & & $\begin{array}{l}\mathbf{P}_{\alpha \mathrm{a}} \\
\mathbf{E}_{\alpha \mathrm{a}} \\
\mathbf{E}_{\alpha \mathrm{a}} \\
\mathbf{E}_{\alpha \mathrm{a}} \\
\mathbf{E}_{\alpha \mathrm{a}} \\
\mathbf{E}_{\alpha \mathbf{a}}\end{array}$ & & & 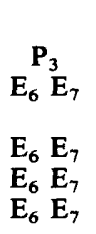 & $\begin{array}{l}P_{1} \\
E_{1} \\
E_{1} \\
E_{1} \\
E_{1} \\
E_{1}\end{array}$ & $\begin{array}{l}E_{\beta R} \\
E_{\beta R} \\
E_{\beta R}\end{array}$ & & $\begin{array}{l}4 \\
6 \\
5 \\
5 \\
4 \\
5\end{array}$ \\
\hline Total & & 2 & 2 & 2 & 5 & 1 & 1 & 1 & 14 & 12 & 18 & 2 & 4 & 12 & 5 & 5 & 22 & 20 & 12 & 6 & \\
\hline
\end{tabular}

* DFP-resistant esterase.

naphthyl butyrate. Type 11 hydrolysed $\alpha$-naphthyl acetate, propionate and butyrate, and indoxyl acetate, whereas types 12 and 13 were active only on $\alpha$-naphthyl acetate and propionate, and indoxyl acetate. Of the type 12 esterases, $K$. oxytoca esterase $\mathrm{E}_{3}$ and $P$. rettgeri esterase $\mathrm{E} \alpha$ were more active on indoxyl acetate than on $\alpha$-naphthyl esters whereas $M$. morganii esterase E $\alpha$ and $E$. hermanii esterase $\mathrm{E}_{2}$ were more active on $\alpha$-naphthyl esters than indoxyl acetate. Types 14 and 15 hydrolysed $\alpha$-naphthyl acetate and propionate. Four types of esterases (types 16 to 19 ) preferentially hydrolysed $\beta$ naphthyl esters and were designated $\beta$-esterases. Type 16 
hydrolysed the three $\beta$-naphthyl esters and usually indoxyl acetate. Within this type, esterases $\beta A$ and $\beta B$ may be distinguished from each other (Goullet, 1975). Types 17 and 18 hydrolysed $\beta$-naphthyl acetate, whereas type 19 hydrolysed strongly indoxyl acetate, and weakly $\beta$-naphthyl acetate.

\section{Distribution of the esterase types within the 36 species}

Table 1 shows the distribution of the 19 types of esterase within the 36 species. Some types were detected in only one species, and were thus species specific, e.g. Serratia odorifera esterase $\mathrm{E}_{5}$ (type 5), Enterobacter sakazakii esterase $\mathrm{ES}_{4}$ (type 6) and $C$. diversus esterase $\mathrm{E}_{1}$ (type 7). Some types were detected only in one group: types 4 and 19 were found in group 4 (Serratia), and types 1 and 11 in group 5 (Proteus, Providencia and Morganella). Esterase I (type 15) was found in group 1 only, and thus appeared to be specific to the $E$. coli-Shigella genospecies (Brenner $\boldsymbol{e t}$ $a l ., 1972 a$, 1973). Some types were detected in distantly related species, e.g. type 3 in Serratia fonticola and $Y$. intermedia, while some types were more widespread, e.g. type 16 ( 22 species), type 10 (18 species) and type 17 (21 species). Most of this latter type of enzyme (esterases $F$ and $E_{1}$ ) stained faintly. Type 9 encompasses esterases which are physicochemically and immunologically unrelated, e.g. E. coli esterase B and Y. pseudotuberculosis esterase $\mathrm{P}_{4}$ (Goullet et al., 1984, 1989).

\section{Multivariate statistical analysis of the 550 strains tested}

The diagram of the first two axes of the MCA done on the distribution of the 19 types of esterases in the 550 strains, which accounted for $25.53 \%$ of the variance, showed the projection of the centres of gravity of the 36 species (Fig. 1). The first axis distinguished Proteus and Providencia species and Enterobacter sakazakii species on their negative values and the Escherichia-Shigella species on their positive values. Serratia species were distinguished by the positive values of the second axis, whereas Salmonella and Yersinia species were distinguished on their negative values. A hierarchical classification was prepared from the first eight axes of the analysis which accounted for $70 \%$ of the variance. Thirty-six classes were selected from the dendrogram obtained and were correlated with the 36 species of enterobacteria. Some species were placed in the same class, e.g. Shigella flexneri and S. sonnei; $C$. freundii and $C$. amalonaticus; $K$. pneumoniae and Enterobacter aerogenes; Serratia marcescens and S. liquefaciens; $Y$. kristensenii and $Y$. aldovae. Some other species were divided into two classes, e.g. Salmonella enterica, Enterobacter sakazakii, Serratia ficaria, Serratia odorifera and $Y$. enterocolitica. Of the

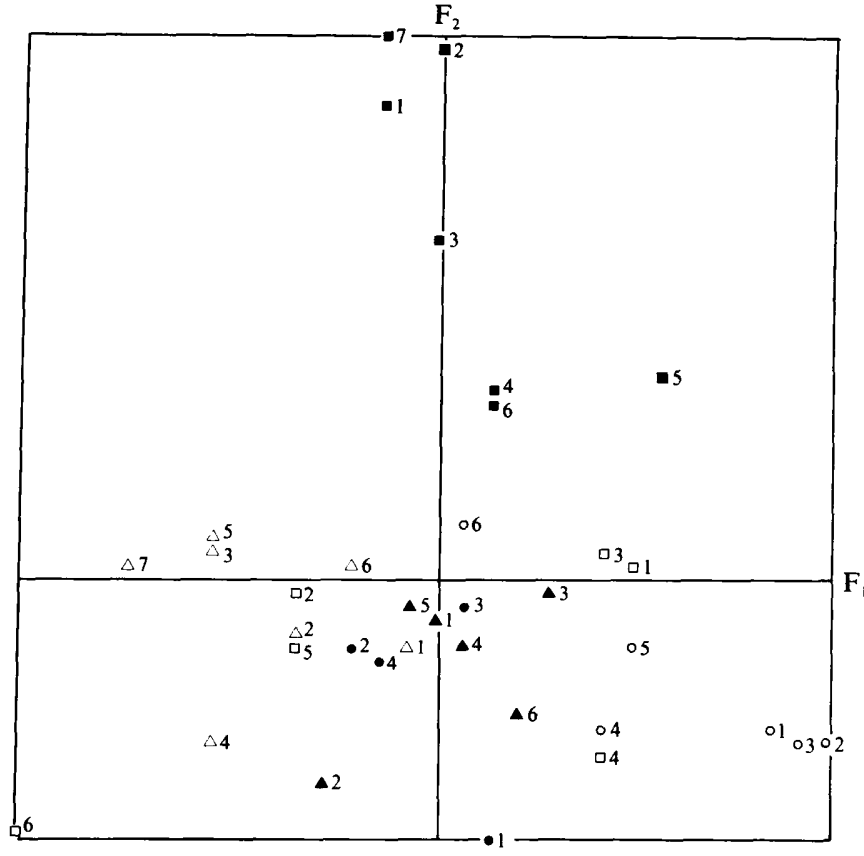

Fig. 1. MCA of the 550 strains. Plot of species scores for the first two principal axes: $O$, group $1 ; \bigcirc$, group $2 ; \square$, group $3 ; \square$, group $4 ; \triangle$, group 5; $\boldsymbol{\Lambda}$, group 6 . For definition of groups, see Methods. Within each group, the species are numbered as in Table 1.

strains of various species $82 \%$ were correctly classified within the corresponding classes (Table 2). These data varied according to the groups considered from $67 \%$ for group 1 (Escherichia-Shigella) to $97 \%$ for group 2 (Salmonella and Citrobacter) (Table 2). Most (91\%) strains of the various groups of species were classified with the corresponding groups of classes. The percentage of accurately classified strains was higher after MCA than after PCA $(76 \%)$. The strains producing all esterases indicated in Table 1 were accurately classified in their species; misclassified strains were restricted to those lacking one, two or three esterases. Thus, it is the absence of information which appears to be responsible for misclassification after MCA. However, these strains could all be easily distinguished from the species in which they were misclassified by at least one uncommon type of esterase and by the electrophoretic mobilities of the detected esterases.

Enzymes such as oxidoreductases and transferases, which are identified in gels by a single substrate, differentiate bacteria only on the basis of mobility variations (Bowman et al., 1967; Baptist et al., 1969; Ochman et al., 1983; Beltran et al., 1989; Reeves et al., 1989; Gargallo-Viola, 1989) and require multiple comparative electrophoretic migrations, whereas esterases, which are indentified from their activity on several substrates, allowed suitable genospecies characterization 
Table 2. Accurately classified strains after hierarchical classification following $M C A$ and PCA of the 550 strains.

\begin{tabular}{|c|c|c|c|c|}
\hline & \multicolumn{4}{|c|}{ No. of strains accurately classified: } \\
\hline & $\begin{array}{c}\text { Into } \\
\text { their species } \\
\text { after MCA }\end{array}$ & $\begin{array}{l}\text { Into their } \\
\text { species group } \\
\text { after MCA }\end{array}$ & $\begin{array}{l}\text { Into } \\
\text { their species } \\
\text { after PCA }\end{array}$ & $\begin{array}{l}\text { Into their } \\
\text { species group } \\
\text { after PCA }\end{array}$ \\
\hline $\begin{array}{l}\text { Escherichia-Shigella } \\
\text { (76 strains) }\end{array}$ & $51(67 \%)$ & $67(88 \%)$ & $54(71 \%)$ & $67(88 \%)$ \\
\hline $\begin{array}{l}\text { Salmonella, Citrobacter } \\
\text { (63 strains) } \\
\text { Klebsiella, Enterobacter }\end{array}$ & $61(97 \%)$ & $61(97 \%)$ & $59(94 \%)$ & $59(94 \%)$ \\
\hline (108 strains) & $90(83 \%)$ & $90(83 \%)$ & $71(66 \%)$ & $94(87 \%)$ \\
\hline $\begin{array}{l}\text { Serratia (104 strains) } \\
\text { Proteus, Providencia, }\end{array}$ & $92(88.5 \%)$ & $102(98 \%)$ & $87(84 \%)$ & $104(100 \%)$ \\
\hline Morganella (96 strains) & $84(86 \cdot 5 \%)$ & $96(100 \%)$ & $80(83 \%)$ & $96(100 \%)$ \\
\hline Yersinia (103 strains) & $75(73 \%)$ & $87(84.5 \%)$ & $66(64 \%)$ & $76(74 \%)$ \\
\hline All groups (550 strains) & $453(82.4 \%)$ & $503(91 \cdot 5 \%)$ & $417(76 \%)$ & $496(90.2 \%)$ \\
\hline
\end{tabular}

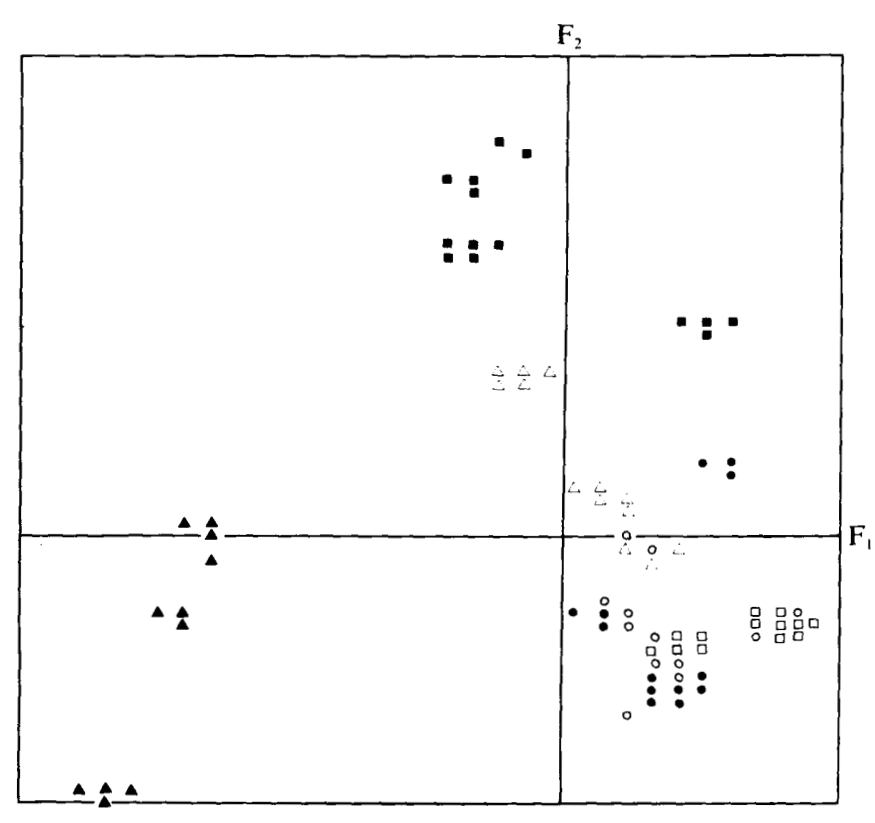

Fig. 2. MCA of strains of group 1. Plot of strain scores for the first two principal axes: $O, E$. coli; $\bullet$, Shigella flexneri; $\square, S$. sonnei; $\square, S$. boydii; $\triangle, S$. dysenteriae; $\triangle, E$. hermanii.

of most of the strains by patterns resulting from combinations of the ESAP.

\section{Multivariate statistical analysis of the six groups of species}

The following analyses consider both the ESAP and the range of mobility of each esterase band.

Group 1. The distribution diagram of the first two axes of the MCA, which accounted for $49.5 \%$ of the variance, shows the projection of the strains (Fig. 2). The first axis distinguished Escherichia hermanii strains on their negative values. Some Shigella boydii and $S$. dysenteriae strains were distinguished by the positive values of the second axis, whereas other $S$. boydii strains and $S$. flexneri serotype 6 were clustered. The hierarchical classification which correlated six classes with the six species of group 1 clearly distinguished $E$. hermanii strains. This species, which has only 40 to $46 \%$ DNA homology with $E$. coli $\mathrm{K} 12$ (Brenner et al., 1982), is very distinct from $E$. coli on the basis of its esterases (Goullet et al., 1986). A single class was formed by eight strains of $S$. dysenteriae whereas five other strains were grouped with most of the $S$. boydii strains. The remaining strains of this latter species constituted a class with the $S$. flexneri serotype 6 strains which were clearly separated from $S$. flexneri serotypes 1 to 5 (Dodd \& Jones, 1982; Goullet, 1980b; Goullet et al., 1983; Goullet \& Picard, 1987; Petrovskaya \& Bondarenko, 1977; Timakov et al., 1972). E. coli strains were distributed in the classes containing $S$. sonnei, S. flexneri and $S$. dysenteriae. These findings agree with previous results showing the clusters of Shigella, as delineated by esterase polymorphism, closer to $E$. coli than to each other, and suggest that they are derived from distinct ancestral strains of $E$. coli (Goullet \& Picard, 1987).

Group 2. The first axis of the MCA (45.2\% of the variance) (Fig. 3) distinguished Salmonella enterica strains on their positive values and $C$. diversus, $C$. amalonaticus and $C$. freundii strains on their negative values, whereas $C$. diversus was distinguished from $C$. amalonaticus and $C$. freundii by the second axis $(20.8 \%$ of the variance). The correlation of the four classes obtained after the hierarchical classification of the four species showed that all $S$. enterica and $C$. diversus strains were distinguished. $S$. enterica was distributed between two classes according to the mobility of esterase $E_{1}$. 


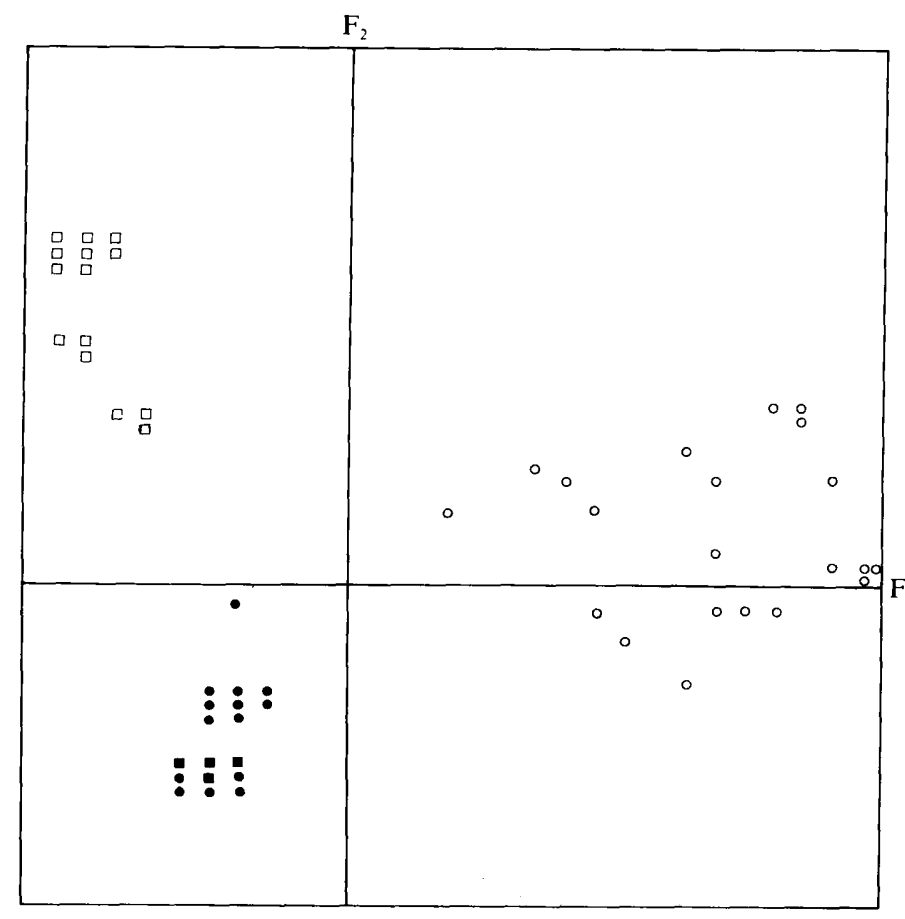

Fig. 3. MCA of strains of group 2. Plot of strain scores for the first two principal axes: $\bigcirc$, Salmonella enterica;, Citrobacter freundii; $\square, C$. diversus; $\mathbf{\square}$, C. amalonaticus.

Interestingly, the two classes corresponded to (i) $S$. enterica subsp. enterica and $S$. enterica subsp. salamae, and (ii) $S$. enterica subsp. arizonae, $S$. enterica subsp. diarizonae and $S$. enterica subsp. houtenae (Le Minor et al., 1982a; Le Minor \& Popoff, 1987). All S. enterica strains displayed the same ESAP, corroborating the fact that this species is a unique DNA homology group (Crosa et al., 1973) (except for S. enterica subsp. bongori strains (Le Minor et al., 1982b; Reeves et al., 1989), which are not included in this study). C. amalonaticus and C. freundii strains could not be separated in this analysis but can be distinguished because the major esterase of all C. amalonaticus strains migrates faster than that of all $C$. freundii strains (Goullet \& Richard, 1977).

Group 3. The first axis of the MCA ( $25 \%$ of the variance) (Fig. 4) distinguished Enterobacter sakazakii, E. cloacae and $K$. oxytoca by their positive values. E. gergoviae (Richard et al., 1976; Brenner et al., 1980c) were distinguished from $E$. aerogenes and $K$. pneumoniae vy the second axis ( $18.5 \%$ of the variance). The hierarchical classification allocated $\mathbf{9 0 . 7 \%}$ of strains within their species. E. sakazakii, which is distinct from $E$. cloacae as shown by DNA reassociation studies (Steigerwalt et al., 1976; Farmer et al., 1980; Izard et al., 1983), was also distinguished by its esterases. All strains of $E$. gergoviae were distinguished, whereas ten strains of $E$. cloacae appeared to be more poorly defined. $K$. pneumoniae and

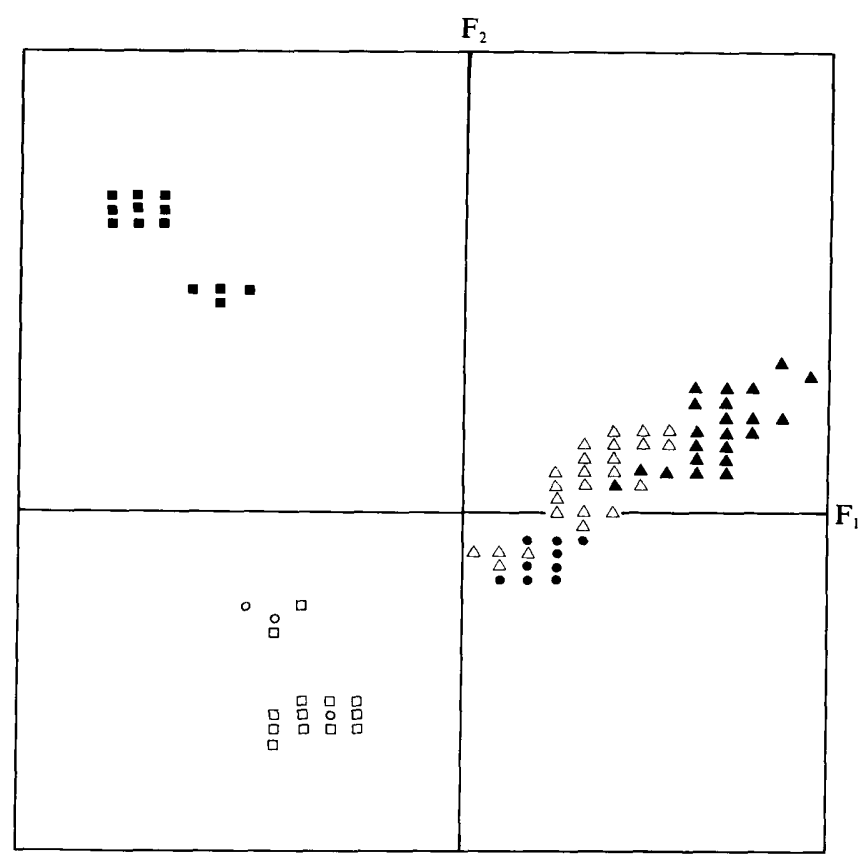

Fig. 4. MCA of strains of group 3. Plot of strain scores for the first two principal axes: $\bigcirc$, Klebsiella pneumoniae;,$K$. oxytoca; $\square$, Enterobacter aerogenes; $\boldsymbol{\square}, \boldsymbol{E}$. gergoviae; $\triangle, E$. cloacae; $\boldsymbol{\Delta}, \boldsymbol{E}$. sakazakii.

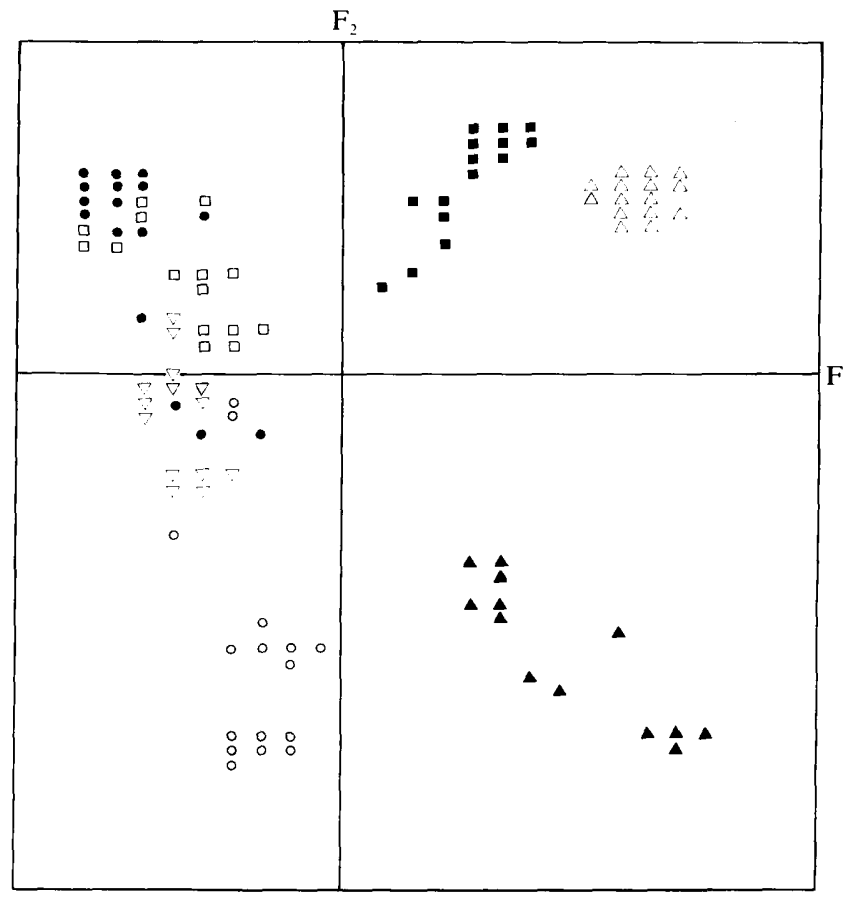

Fig. 5. MCA of strains of group 4. Plot of strain scores for the first two principal axes: $O$, Serratia marcescens; $O, S$. liquefaciens; $\square, S$. plymuthica; $\square, S$. marinorubra; $\triangle, S$. odorifera; $\Lambda, S$. ficaria $\nabla, \boldsymbol{S}$. fonticola. 


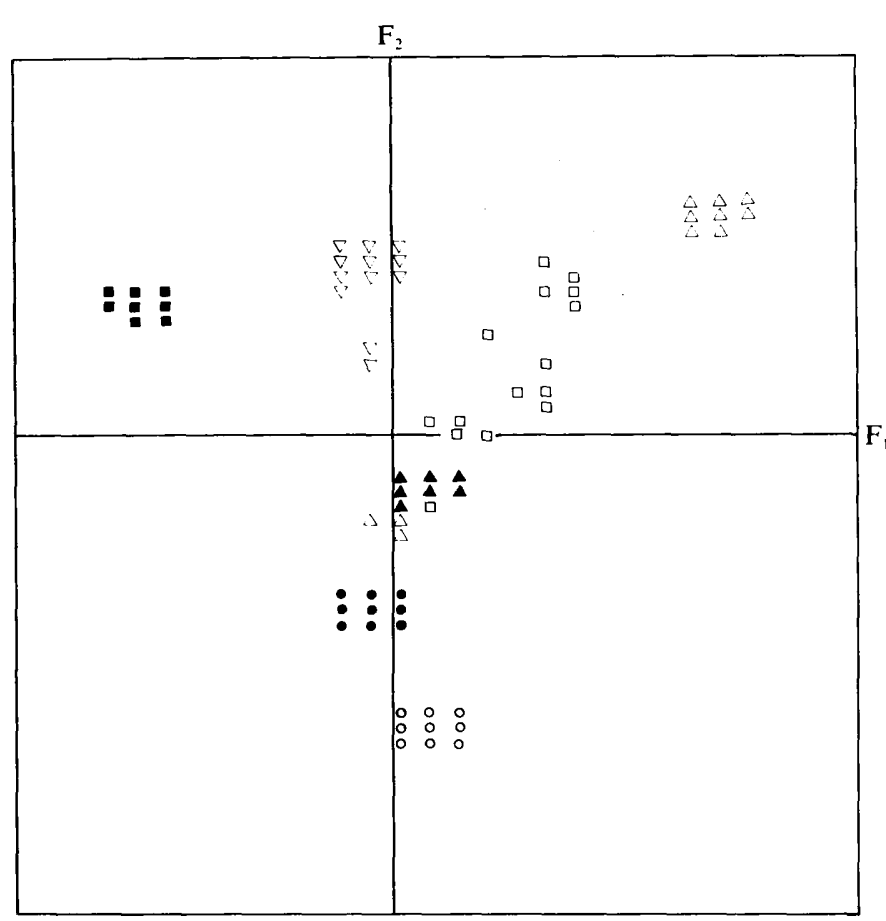

Fig. 6. MCA of strains of group 5. Plot of strain scores for the first two principal axes: $\bigcirc$, Proteus vulgaris; O Proteus mirabilis; $\square$, Providencia alcalifaciens; $\square$, Providencia stuartii; $\triangle$, Providencia rettgeri; $\Delta$, Providencia rustigianii; $\nabla$, Morganella morganii.

$E$. aerogenes, which are genotypically related (Brenner $\boldsymbol{e t}$ al., 1972b), were not distinguished by their ESAP, but were delineated by the electrophoretic mobilities of their esterases (Goullet, 1980a).

Group 4. The distribution diagram of the first two axes of the analysis, which accounted for $31.9 \%$ of the variance (Fig. 5), distinguished Serratia marinorubra and $S$. odorifera by their positive values and $S$. fonticola and $S$. marcescens by their negative values. $S$. ficaria was distinguished by the negative values of the second axis and $S$. liquefaciens and $S$. plymuthica by the negative values of the first axis. Of the strains of all the Serratia species, $93.3 \%$ were distinguished by the hierarchical classification. One $S$. liquefaciens strain was misclassified in $S$. marcescens and three strains of the latter species were misclassified in the former. This result shows that the two species are closely related according to their esterase polymorphism. All strains of S. plymuthica and of $S$. fonticola were correctly classified. $S$. fonticola appeared to be related to other Serratia based on their esterase patterns, as was previously demonstrated by DNA reassociation studies (Crosa et al., 1974; Gavini et al., 1979).

Group 5. The first axis of the MCA $(21.5 \%$ of the variance) (Fig. 6) separated Providencia stuartii from $P$.

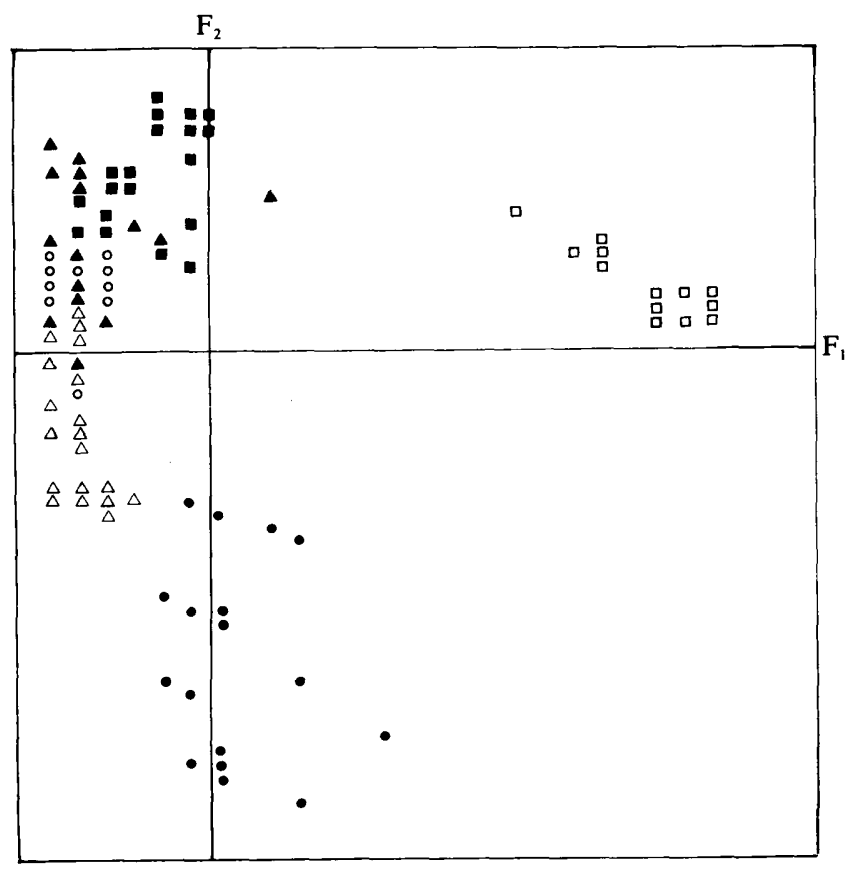

Fig. 7. MCA of strains of group 6. Plot of strain scores for the first two principal axes: $O$, Yersinia pseudotuberculosis;,$Y$, enterocolitica; $\square$, Y. intermedia; $\square, Y$. frederiksenii; $\triangle, Y$. kristensenii; $\Delta, Y$. aldovae.

rettgeri, whereas the second axis $(18 \%$ of the variance) distinguished $M$. morganii, $P$. alcalifaciens, $P$. rustigianii, $P$. mirabilis and $P$. vulgaris. The hierarchical classification allowed identification of $88.7 \%$ of the strains within their species. The least well classified species was $P$. alcalifaciens where seven strains were misclassified by the statistical computations. However, these strains, which included several null alleles, were distinguished from other species by other esterases (Goullet \& Picard, 1985). The esterase data for Providencia were in agreement with the genetic divergence measured by DNA reassociation studies (Brenner et al., 1978).

Group 6. The first axis of the MCA $(21.2 \%$ of the variance) (Fig. 7) distinguished $Y$. intermedia by its positive values whereas the second axis $(15.4 \%$ of the variance) separated $Y$. enterocolitica from $Y$. frederiksenii. The hierarchical classification allowed delineation of $93.2 \%$ of strains within the six Yersinia species. $Y$. aldovae was distinguished whereas $Y$. frederiksenii was the least clearly separated species with five misclassified strains. This species was very heterogeneous in terms of esterases with frequent null alleles and several other esterases detected in only a few strains (Goullet \& Picard, 1988), and is, in fact, composed of several DNA homology groups (Brenner et al., 1980a; Ursing et al., 1980).

To summarize, the electrophoretic mobilities of esterases enabled the delineation of all interrelated species which 


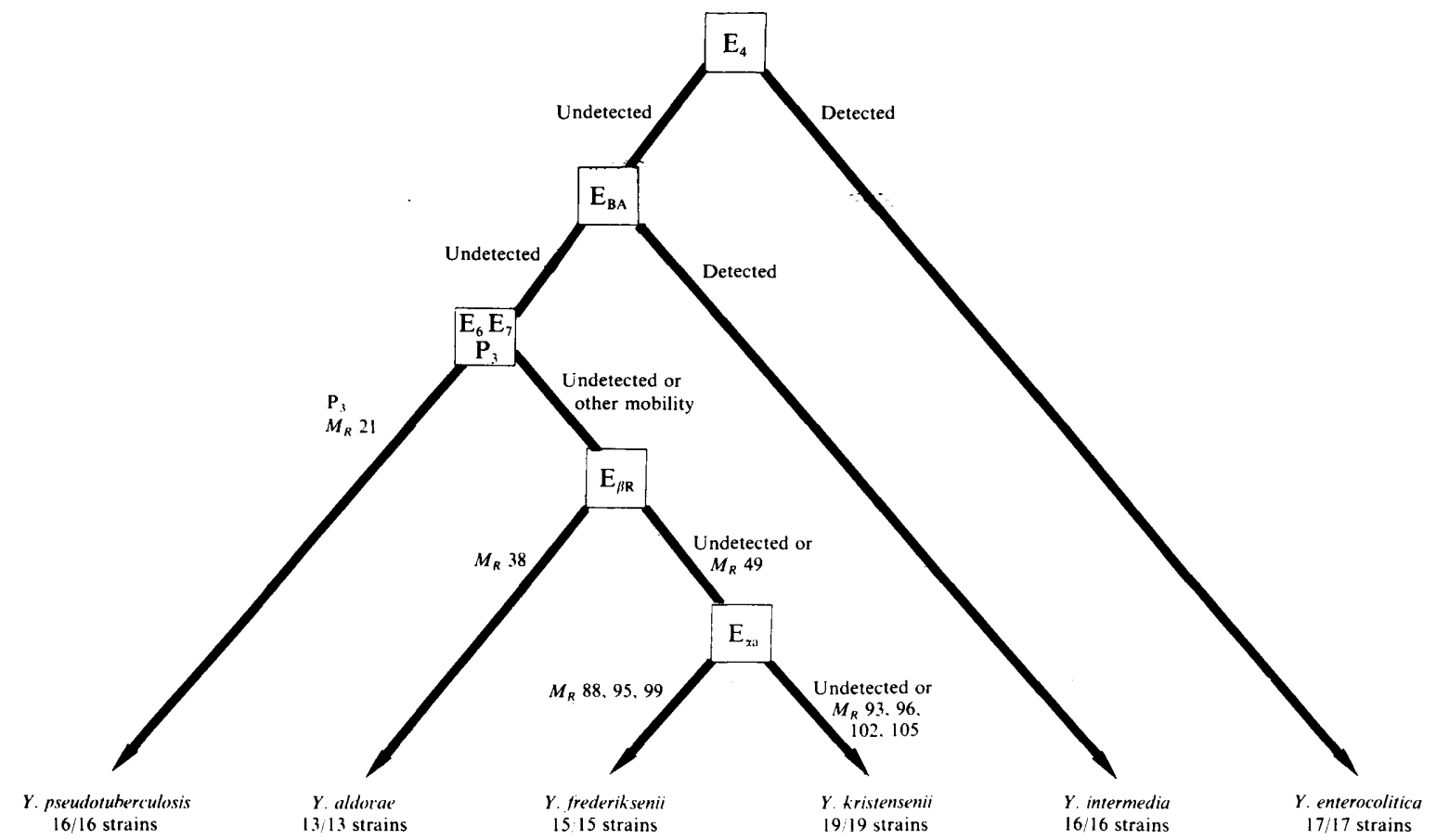

Fig. 8. Binary segmentation tree for the characterization of Yersinia strains. $E_{4}$, esterase $E_{4} ; E_{B A}$, esterase $E_{B A} ; E_{6}$, esterase $E_{6} ; E_{7}$, esterase $E_{7} ; P_{3}$, esterase $P_{3} ; E_{\beta R}$, esterase $E_{\beta R} ; E_{\alpha a}$, esterase $E_{\alpha a}$.

were placed in the same classes after MCA of the ESAP data.

\section{Binary segmentation tree for the characterization of Yersinia strains}

The smallest number of characters providing species identification of Yersinia strains by esterase data was identified by preparing a binary segmentation tree with the 96 Yersinia strains correctly classified by MCA. Six characters were sufficient (Fig. 8): the first two were the existence of esterase $\mathrm{E}_{4}$ in $Y$. enterocolitica and esterase $\mathrm{E}_{\mathrm{BA}}$ in $Y$. intermedia; the other four were particular electrophoretic variants. Thus the $Y$. enterocolitica-like species, which were in some cases distinguished from each other and from Y. enterocolitica sensu stricto by a few conventional phenotypic traits (Brenner et al., $1980 \mathrm{~b}$; Ursing et al., 1980; Bercovier et al., 1980, 1984), were readily characterized by the electrophoretic polymorphism of their esterases.

The authors thank Madame C. Gaillard and Madame N. Hautier for technical assistance. This work was supported by grants from the Conseil Scientifique de la Faculté Xavier Bichat (Université Paris VII).

\section{References}

BaPtist, J. N., Shaw, C. H. \& MaNdel, M. (1969). Zone electrophoresis of enzymes in bacterial taxonomy. Journal of Bacteriology 99,180 188.
Beltran, P., Musser, J. M., Helmuth, R., Farmer, J. J., III, Frerichs, W. M., Wachsmuth, I. K., Ferris, K., McWhorter, A. C., Wells, J. G., Cravioto, A. \& Selander, R. K. (1989). Toward a population genetic analysis of Salmonella: genetic diversity and relationships among strains of serotypes $S$. choleraesuis, $S$. derby, $S$. dublin, $S$. enteritidis, $S$. heidelberg, $S$. infantis, $S$. newport and $S$. typhimurium. Proceedings of the National Academy of Sciences of the United States of America 85, 7753-7757.

Bercovier, H., Ursing, J., Brenner, D. J., Steigerwalt, A. G., Fanning, G. R., Carter, G. P. \& Mollaret, H. H. (1980). Yersinia kristensenii: a new species of Enterobacteriaceae composed of sucrose-negative strains (formerly called atypical Yersinia enterocolitica or Yersinia enterocolitica like). Current Microbiology 4, 219224.

Bercovier, H., Steigerwalt, A. G., Guiyoule, A., HuntleyCARTER, G. \& BRENNER, D. J. (1984). Yersinia aldovae (formerly Yersinia enterocolitica-like group X2): a new species of Enterobacteriaceae isolated from aquatic ecosystems. International Journal of Systematic Bacteriology 34, 166-172.

Bowman, J. E., Brubaker, R. R., Frischer, H. \& Carson, P. E. (1967). Characterization of enterobacteria by starch-gel electrophoresis of glucose-6-phosphate dehydrogenase and phosphogluconate dehydrogenase. Journal of Bacteriology 94, 544-551.

Brenner, D. J., Fanning, G. R., Skerman, F. J. \& Falkow, S. (1972a). Polynucleotide sequence divergence among strains of Escherichia coli and closely related organisms. Journal of Bacteriology 109, 953-965.

Brenner, D. J., Steigerwalt, A. G. \& Fanning, G. R. (1972b). Differentiation of Enterobacter aerogenes from Klebsiellae by deoxyribonucleic acid reassociation. International Journal of Systematic Bacteriology 22, 193-200.

Brenner, D. J., Fanning, G. R., Miklos, G. V. \& Steigerwalt, A. G. (1973). Polynucleotide sequence relatedness among Shigella species. International Journal of Systematic Bacteriology 23, 1-7.

Brenner, D. J., Farmer, J. J., III, Fanning, G. R., Steigerwalt, A. G., Klykken, P., Wathen, H. G., Hickman, F. W. \& Ewing, W. H. (1978). Deoxyribonucleic acid relatedness of Proteus and 
Providencia species. International Journal of Systematic Bacteriology 28, 269-282.

Brenner, D. J., Ursing, J., Bercovier, H., Steigerwalt, A. G., Fanning, G. R., Alonso, J. M. \& Mollaret, H. H. (1980a) Deoxyribonucleic acid relatedness in Yersinia enterocolitica and Yersinia enterocolitica-like organisms. Current Microbiology 4, 195 200.

Brenner, D. J., Bercovier, H., Ursing, J., Alonso, J. M., Steigerwalt, A. G., Fanning, G. R., Carter, G. P. \& Mollaret, H. H. (1980b). Yersinia intermedia: a new species of Enterobacteriaceae composed of rhamnose-positive, melibiose positive, raffinosepositive. strains (formerly called Yersinia enterocolitica or Yersinia enterocolitica-like), Current Microbiology 4, 207-212.

BrenNer, D. J., Richard, C., Stetoerwalt, A. G., Asbury, M. A. \& MANDEL, M. $(1980 c)$. Enterobacter gergoviae sp: nav. a new species of Enterobacteriaceae found in clinical specimens and the environment. International Journal of Systematic Bacteriology 30, 1-6.

Brenner, D. J., Davis, B. R., Steigerwalt, A. G., Riddle, C. F., MCWhorter, A. C., Allen, S. D., FARMer, J. J., III, SAItoH, Y. \& FANNING, G. R. (1982). Atypical biogroups of Escherichia coli found in clinical specimens and description of Escherichia hermanii sp. nov. Journal of Clinical Microbiology 15, 703-713.

Crosa, J. H., Brenner, D. J., EwING, W. H. \& Falkow, S. (1973). Molecular relationships among the Salmonelleae. Journal of Bacteriology 115, 307-315.

Crosa, J. H., Steigerwalt, A. G., Fanning, G. R. \& Brenner. D. J (1974). Polynucleotide sequence divergence in the genus Citrobacter. Journal of General Microbiology 83, 271-282.

DODD, C. E. R. \& JoNES, D. (1982). A numerical taxonomic study of the genus Shigella. Journal of General Microbiology 128, 1933-1957.

Farmer, J. J., III, Asbury, M. A., Hickman, F. W., BrenNer, D. J. \& The ENTERobacteriaceae StUdy Group (1980). Enterobacter sakazakii: a new species of Enterobacteriaceae isolated from clinical specimens. International Journal of Systematic Bacteriology 30, 569-584.

Gargallo-Viola, D. (1989). Enzyme polymorphism, prodigiosin production and plasmid fingerprints in clinical and naturally occurring isolates of Serratia marcescens. Journal of Clinical Microbiology 27, 860-868.

Gavini, F., Ferragut, C., Izard, D., Trinet, P. A., Leclerc, H., LEFEBVRE, B. \& Mosset, A. A. (1979). Serratia fonticola, a new species from water. International Journal of Systematic Bacteriology 29, 91-101.

Goullet, PH. (1973). An esterase zymogram of Escherichia coli. Journal of General Microbiology 77, 27-35.

Goullet, PH. (1975). Esterase zymograms of Proteus and Providencia. Journal of General Microbiology 87, 97-106.

GoulLET, PH. (1977). Relationships between electrophoretic patterns of esterases from Salmonella. Journal of General Microbiology 98, 535-542.

Goullet, PH. (1978). Characterization of Serratia marcescens, $S$. liquefaciens, $S$. plymuthica and $S$. marinorubra by the electrophoretic patterns of their esterases. Journal of General Microbiology 108 , 275-281.

GoulLET, PH. (1980a). Distinctive electrophoretic patterns of esterases from Klebsiella pneumoniae, $K$. oxytoca, Enterobacter aerogenes and E. gergoviae. Journal of General Microbiology 117, 483-491.

GoULLET, PH. $(1980 b)$. Esterase electrophoretic pattern relatedness between Shigella species and Escherichia coli. Journal of General Microbiology 117, 493-500.

Goullet, PH. (1981). Characterization of Serratia odorifera, $S$. fonticola and $S$. ficaria by the electrophoretic patterns of their esterases. Journal of General Microbiology 127, 161-167.

Goullet, PH. \& PICARD, B. (1984). Distinctive electrophoretic and isoelectric focusing patterns of esterases from Yersinia enterocolitica and Yersinia pseudotuberculosis. Journal of General Microbiology 130 , 1471-1480.

Goullet, Ph. \& PiCard, B. (1985). Etude du polymorphisme électrophorétique des lactate-, malate- et glutamate-deshydrogenases, de la phosphatase acide et des esterases de Providencia alcalifaciens, $P$. stuartii et $P$. rustigianii. Annales de l'Institut Pasteur/ Microbiologie 136A, 347-358.
Goullet, Ph. \& Picard, B. (1986). Characterization of Enterobacter cloacae and $E$. sakazakii by electrophoretic polymorphism of acid phosphatase, esterases, and glutamate, lactate and malate dehydrogenase. Journal of General Microbiology 132, 3105-3112.

Goullet, PH. \& PICARD, B. (1987). Differentiation of Shigella by esterase electrophoretic polymorphism. Journal of General Microbiology 133, 1005-1017.

Goullet, PH. \& PiCARD, B. (1988). Characterization of Yersinia enterocolitica, $Y$. intermedia, $Y$. aldovae, $Y$. frederiksenii, $Y$. kristensenii and $Y$. pseudotuberculosis by electrophoretic polymorphism of acid phosphatase, esterases, and glutamate and malate dehydrogenases. Journal of General Microbiology 134, 317-325.

Goullet, Ph. \& Richard, C. (1977). Distinctive electrophoretic patterns of esterases from Levinea malonatica, Levinea amalonatica and Citrobacter. Journal of General Microbiology 98, 543-549.

Goullet, Ph., Picard, B. \& Toucas, M. (1983). Differenciation du sérotype 6 des sérotypes 1-5 de Shigella flexneri par électrophorèse et focalisation isoélectrique de leurs estérases. Annales de Microbiologie (Institut Pasteur) 134B, 269-276.

Goullet, Ph., Picard, B. \& Laget, P. F. (1984): Purification and properties of carboxylesterase B of Escherichia coli. Annales de Microbiologie (Institut Pasteur) 135A, 375-387.

Goullet, Ph., Picard, B. \& Richard, C. (1986). Caracterisation de Escherichia hermanii par électrophorèse des estérases, de la phosphatase acide et des glutamate- et malate-déshydrogenases. Annales de l'Institut Pasteur/Microbiologie 137A, 295-299.

Goullet, Ph., Branger, C., Philippe, J. C. \& Picard, B. (1989). Isolation and properties of carboxylesterase $\mathrm{P}_{4}$ from Yersinia pseudotuberculosis: Research in Microbiology 140, 221-234.

Gueguen, A. \& NaKache, J. P. (1988). Methode de discrimination basée sur la construction d'un arbre de décision binaire. Revue de Statistique Appliquée 36, 19-38.

GreEnaCre, M. J. (1984). Theory and Applications of Correspondences. London: Academic Press.

IZARD, D., RichaRD, C. \& LeCleRC, H. (1983). DNA relatedness between Enterobacter sakazakii and other members of the genus Enterobacter. Annales de Microbiologie (Institut Pasteur) 134A, 241245.

Lebart, L., Morineau, A. \& Warwick, K. M. (1984). Multivariate descriptive analysis: correspondence analysis and related techniques for large matrices. New York: Wiley-Interscience.

LE MinOR, L. \& POPOFF, M. (1987). Request for an opinion. Designation of Salmonella enterica sp. nov., nom. rev., as the type and only species of the genus Salmonella. International Journal of Systematic Bacteriology 37, 465-468.

Le Minor, L., Veron, M. \& Popoff, M. (1982a). Taxonomie des Salmonella. Annales de Microbiologie (Institut Pasteur) 133B, 223-243.

Le Minor, L., Veron, M. \& Popoff, M. (1982b). Proposition pour une nomenclature des Salmonella. Annales de l'Institut Pasteur 133B, 245-254.

LENNOX, E. S. (1955). Transduction of linked genetic characters of the host by bacteriophage PI. Virology 1, 190-206.

Ochman, H., Whittam, T. S., Caugant, D. A. \& Selander, R. K. (1983). Enzyme polymorphism and genetic population structure in Escherichia coli and Shigella. Journal of General Microbiology 129, 2715-2726.

Petrovskaya, V. G. \& Bondarenko, V. M. (1977). Recommended corrections to the classification of Shigella flexneri on a genetic basis. International Journal of Systematic Bacteriology 27, 171-175.

Picard, B. \& Goullet, PH. (1985). Comparative electrophoretic profiles of esterases, and of glutamate, lactate and malate dehydrogenases, from Aeromonas hydrophila, A. caviae and A. sobria. Journal of General Microbiology 131, 3385-3391.

Reeves, M. W., Evins, G. M., Heiba, A. A., Plikaytis, B. D. \& FARMER, J. J., III. (1989). Clonal nature of Salmonella typhi and its genetic relatedness to other Salmonellae as shown by multilocus enzyme electrophoresis, and proposal of Salmonella bongori comb. nov. Journal of Clinical Microbiology 27, 313-320.

Richard, C., Joly, B., Sirot, J., Stoleru, G. H. \& Popoff, M. (1976). Étude de souches de Enterobacter appartenant à un groupe particulier proche de E. aerogenes. Annales de Microbiologie (Institut Pasteur) 127A, 545-548. 
Steigerwalt, A. G., Fanning, G. R., Fife Asbury, M. A. \& BRENNER, D. J. (1976). DNA relatedness among species of Enterobacter and Serratia. Canadian Journal of Microbiology 22, 121137.

Tenenhaus, M. \& Young, F. W. (1985). An analysis and synthesis of multiple correspondence analysis, optimal scaling, dual scaling, homogeneity analysis and other methods for quantifying categorical multivariate data. Psychometrika 50, 91-119.

Timakov, V. D., Petrovskaya, V. G., Bondarenko, V. M. \& KHOMENKo, N. A. (1972). Genetic data concerning Shigella flexneri serotypes 5 and 6. International Journal of Systematic Bacteriology 22, 149-154.
URIEL, J. (1963). Caracterisation d'enzymes par électrophorèse en gélose. In Technique de Laboratoire, pp. 930-935. Edited by J. Loiseleur. Paris: Masson.

URIEL, J. (1966). Méthode d'électrophorèse dans des gels d'acrylamideagarose. Bulletin de la Société de Chimie Biologique 48, 969-982.

Ursing, J., Brenner, D. J., Bercovier, H., FanNing, R., Steigerwalt, A. G., Brault, J. \& Mollaret, H. H. (1980). Yersinia frederiksenii: a new species of Enterobacteriaceae composed of rhamnose-positive strains (formerly called atypical Yersinia enterocolitica or Yersinia enterocolitica-like). Current Microbiology 4, 213-217. 